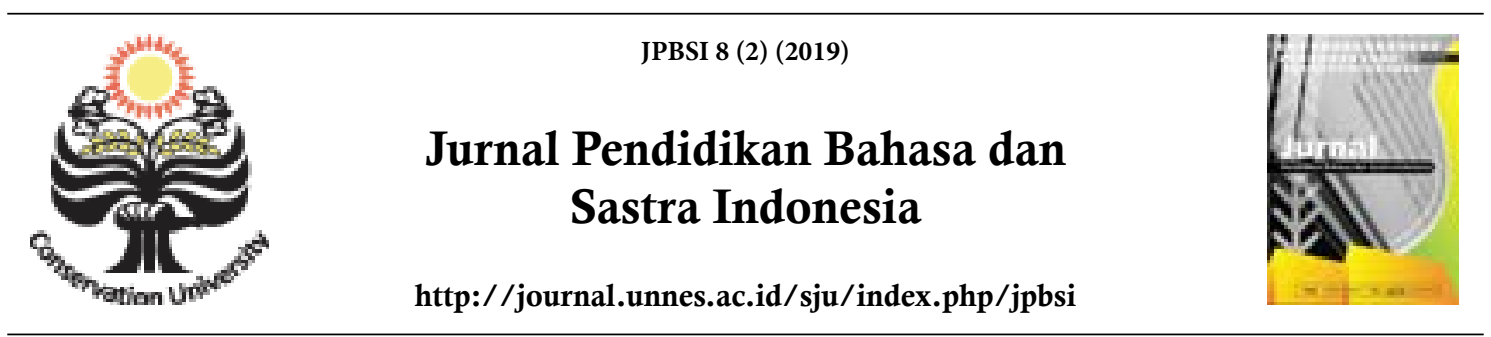

\title{
KEMAMPUAN MENCERITAKAN VIDEO HIKAYAT ABU NAWAS SISWA KELAS X IPA 1 MAN 1 SURAKARTA MELALUI KETERAMPILAN MENULIS
}

\author{
Farida Yufarlina Rosita ${ }^{\bowtie}$ Ferdian Achsani \\ Universitas Islam Negeri Surakarta, Indonesia
}

\section{Info Artikel}

Sejarah Artikel:

Diterima Mei 2019

Disetujui Juni 2019

Dipublikasikan November 2019

\section{Keywords:}

Student Ability; Write; Text of Story.

\begin{abstract}
Abstrak
Penelitian deskriptif kualitatif ini mendeskripsikan tentang kemampuan menulis siswa kelas X IPA 1 di MAN 1 Surakarta. Penelitian yang dilakukan pada tahun 2018 ini bertujuan untuk mengetahui sampai sejauh mana kemampuan menulis siswa dengan bantuan media berupa video hikayat abu nawas dengan cara mendeskripsikan melalui bentuk kata-kata maupun tulisan. Subjek penelitian yaitu kelas X IPA 1 dengan siswa yang berjumlah 34 orang. Data yang diambil untuk mengetahui keterampilan menulis siswa dengan menggunakan metode penilaian tes tertulis. Teknik analisis data bertujuan untuk membeirkan gambaran mengenai kemampuan menulis siswa di kelas X IPA 1. Hasil penelitian menunjukkan bahwa kemampuan siswa dalam keterampilan menulis menunjukkan kategori baik. 4 siswa mendapat kategori nilai kurang, 13 siswa mendapat kategori nilai cukup, dan 17 siswa mendapat kategori nilai baik. Hasil penelitian ini dapat dijadikan acuan bagi guru bahasa Indonesia di MAN 1 Surakarta maupun di sekolah lain untuk meningkatkan keterampilan berbahasa siswa.
\end{abstract}

\begin{abstract}
This descriptive qualitative study describes the writing ability of class $X$ students of IPA 1 in MAN 1 Surakarta. The research conducted in 2018 aims to determine the extent to which students' writing skills with the help of the media are in the form of the video of abu nawas saga by describing it through the form of words and writing. The research subjects were class X IPA 1 with 34 students. Data was taken to find out students' writing skills using the written test assessment method. The data analysis technique aims to provide an overview of the writing skills of students in class $X$ Science 1 . The results of the study show that students' abilities in writing skills show good categories. 4 students get a less value category, 13 students get enough value categories, and 17 students get good value categories. The results of this study can be used as a reference for Indonesian language teachers in MAN 1 Surakarta and in other schools to improve students' language skills.
\end{abstract}




\section{PENDAHULUAN}

Tujuan akhir dari pembelajran bahasa Indonesia adalah agar para siswa terampil dalam menggunakan kemampuan berbahasa, yaitu terampil menyimak, terampil berbicara, terampil membaca dan terampil menulis (Tarigan, 2015: 2). Dari pendapat yang disampaikan oleh Tarigan tersebut, maka tujuan akhir pembelajaran bahasa Indonesia adalah siswa harus mampu menguasai keempat keterampilan berbahasa. Pembelajaran bahasa Indonesia merupakan mata pelajaran di sekolah yang berperan penting untuk mengajarkan keterampilan berbahasa. Dalam pembelajaran bahasa Indonesia, guru berperan sebagai wadah untuk mengembangkan atau membentuk keterampilan berbahasa siswa. Sesuai pendapat Kurniawan (2015)yang menyatakan bahwa pembelajaran bahasa Indonesia diorientasikan secara terpadu untuk menjadikan siswa terampil dalam berkomunikasi dengan menguasai keempat keterampilan berbahasa tersebut secara serentak. $\mathrm{Hal}$ tersebut menjadi salah satu tugas pokok guru bahasa Indonesia untuk mampu mengembangkan keterampilan berbahasa siswa. Meskipun tidak dapat dipungkiri bahwa seluruh mata pelajaran juga bereperan penting dalam mengajarkan keterampilan berbahasa peserta didik, akan tetapi pembelajaran bahasa Indonesia adalah pembelajaran yang paling pokok dalam mempelajari keterampilan berbahasa.

Guru memiliki peranan yang penting dalam mengajarkan keempat keterampilan berbahasa. Peran guru di setiap jenjang sekolah mulai dari jenjang TK sampai SMA sangat besar dalam mengajarkan keterampilan berbahasa. Pasalnya, siswa akan lebih mudah mencerna apa yang disampaikan oleh guru daripada mereka harus belajar sendiri. Baik buruk kualitas pengajaran yang dilakukan oleh guru sangat mempengaruhi perkembangan berbahasa siswa. Dengan upaya-upaya pengajaran keempat keterampilan berbahasa tersebut, baik secara mandiri maupun terintegrasi, diharapkan siswa mampu berbahasa dengan baik dan benar (Rohmadi, Sugiri, \& Aninditya, 2014: 39).

Peran guru tidak akan dapat terealisasikan jika siswa sendiri tidak memiliki greget dan keinginan untuk berkembang. Peran guru sebagai satuan pendidikan yang bertugas untuk mencerdaskan peserta didik tidak dapat terealisasikan tanpa ada semangat ingin berkembang dari peserta didik. Untuk itu, Tarigan (2008: 1), kembali menegaskan bahwa keempat keterampilan berbahasa tersebut hanya dapat diperoleh dan dikuasai dengan jalan praktik dan banyak latihan. Tanpa adanya kebiasaan ataupun latihan, seseo- rang akan sulit dalam mengembangkan keempat keeterampilan berbahasa tersebut. Keterampilan berbaahsa diperoleh dari masa kecil kita belajar menyimak bahasa, kemudian berbicara, setelah itu kita belajar membaca dan menulis (Suyudi, Mardian, and Wahyuni, 2016).

Meskipun demikian tidak dapat dipungkiri bahwa masih banyak pendidik (guru) lebih dominan memberikan pengetahuan tentang berbahasa daripada memberikan penguasaan berbahasa Indonesia yang baik dan benar (Chaer, 2013: 36). Masih banyak ditemukan guru yang mengajarkan pengetahuan berbahasa daripada mengajarkan keterampilan berbahasa pada siswa. Hal ini disebabkan karena kurangnya motivasi guru untuk mengembangkan kemampuan belajar siswa. Akibatnya dampak yang ditimbulkan pada siswa adalah mereka kurang menguasai keempat keterampilan berbahasa. Padahal dalam kurikulum 2013, pembelajaran bahasa Indonesia lebih menekankan pada pembelajaran berbasis teks dan hasil akhir dari setiap pembelajaran adalah menekankan pada hasil karya. Dalam pembelajaran berbasis teks tersebut, seharusnya dimanfaatkan oleh guru untuk dijadikan peluang dalam mengembangkan keterampilan berbahasa siswa. Untuk itu guru dapat menggunakan metode maupun media pembelajaran yang digunakan dengan lebih meningkatkan keikutsertaan siswa dalam proses pembelajaran (Lestari \& Wahyuni, 2016). Melalui metode maupun media pembelajaran tersebut diharapkan siswa dapat mengembangkan keterampilan berbahasa.

Keterampilan berbahasa menjadi salah satu hasil akhir dalam setiap tema pembelajaran bahasa Indonesia. Misalnya dalam keterampilan menulis. Seperti yang kita ketahui bahwa menulis merupakan sebuah proses menuangkan pikiran dalam bentuk kata-kata ataupun tulisan. Menulis merupakan tahap akhir dari keterampilan berbahasa. Hal tersebut sesuai dengan yang disampaikan oleh Sari (2007) bahwa menulis merupakan sebuah proses kompleks dimana penulis dapat mengungkapkan segala yang dipikirkannya menjadi sesuatu yang nyata. Melalui pedapat tersebut dapat dipahami bahwa menulis merupakan hasil olah pikir seseorang berupa karya yang dapat dilihat. Lain halnya dengan Sari, Slamet (2014:151152) menegaskan bahwa menulis bukan hanya berupa melahirkan pikiran atau perasaan, melainkan juga merupakan pengungkapan ide, pengetahuan, ilmu dan pengalaman hidup seseorang dalam bahasa tulis.

Salah satu kegiatan menulis dapat dilakukan pada materi pembelajaran teks hikayat. Teks hikayat merupakan salah satu jenis teks yang di- 
pelajari oleh siswa kelas X SMA. Pemanfaatan teks hikayat sebagai materi pembelajaran dapat dilihat pada KD 3.7, 3.8, 3.7, 4.8. Pada KD 4.7 (Menceritakan kembali isi cerita rakyat (hikayat) yang didengar dan dibaca dan 4.8 (Mengembangkan cerita rakyat (hikayat) ke dalam bentuk cerpen dengan memerhatikan isi dan nilai-nilai) menuntut siswa untuk mampu menceritakan kembali cerita rakyat (hikayat) yang sudah disimak. Pada KD 4.7, siswa dituntut untuk mampu mengembangkan keterampilan berbahasa menyimak, membaca dan menulis dan membaca. Pada KD 4.8 menuntut siswa untuk mampu mengembangkan keterampilan berbahasa dalam bentuk tulisan ataupun lisan.

Teks Hikayat merupakan salah satu ragam cerita rakyat yang setiap tokoh dalam ceritanya memiliki kesaktian yang luar biasa. Karim (2015: 18) menyebutkan beberapa fungsi hikayat yaitu: menumbuhkan jiwa kepahlawanan atau patriotisme, sebagai sarana pendidikan atau didaktis, sebagai medium mengabadikan atau mengekalkan segala kejadian atau peristiwa yang dialami para raja, seta sebagai media hiburan, sekadar menyenangkan hati, atau dengan tujuan tertenu si pencerita. Hadirnya teks hikayat dalam pembelajarn bahasa Indonesia bertujuan untuk memberika nilai didik kepada siswa-siswi, sesuai dengan fungsi sastra. Dengan menempatkan materi teks hikayat ke dalam pembelajaran bahasa indoensia, siswa diharpkan mampu untuk menguasai keempat keterampilan berbahasa dan mampu mengambil nilai-nilai yang terdapat dalam teks hikayat.

Selain menceritakan dari hal yang dibaca dan didengar, guru juga dapat menggantikannya dengan mengajak siswa menceritakan kembali dari video teks hikayat yang dapat mereka saksikkan. Seiring Perkembangan teknologi yang semakin pesat tidak menutup kemungkinan bahwa teknologi turut mempengaruhi jalannya proses pendidikan, terutama dalam pembelajaran. Guru dapat memanfaatkan perkembangan teknologi sebagai bahan ajar atau media pembelajaran. Jihad (2013:107) menyatakan bahwa Penggunaan media secara kreatif akan memungkinkan siswa untuk belajar lebih baik dan dapat meningkatkan penampilan mereka sesuai dengan tujuan yang ingin dicapai. Dengan menggunakan media sebagai bahan pembelajaran diharapkan dapat memberikan perangsang bagi siswa agar terjadi proses belajar yang kondusif (Solihatin, 2013: 185). Maka dari itu peran media dalam proses pembelajaran sangat dibutuhkan. Dengan menggunakan media, maka pesan yang ingin disampaikan kepada peserta didik akan mudah dipaha- mi dan terarah.

Melalui penggunaan media video dalam pembelajaran teks hikayat, guru dapat meminta siswa untuk menceritakan kembali apa yang sudah mereka saksikan dalam bentuk tulisan maupun lisan. Penggunaan video sebagai media pembelajaran sudah melalui berberapa pertimbangan. Salah satu alasan memilih menggunakan media video karena dengan penggunaan video, akan lebih memudahkan siswa dalam bercerita. Jika menggunakan media bacaan, hal yang ditakutkan siswa hanya akan menyalin (copy paste) dari bacaan. Dengan menggunakan media video, sebagai perangsang bagi siswa, diharapkan dapat membantu siswa dalam mengembangkan kemampan berbahasa (menyimak dan menulis). Selama ini dalam hal menulis kemampuan siswa masih dapat dikatakan belum begitu maksimal karena setiap individu pasti menemui hambatan ketika menulis. Seperti yang disebutkan Kuncoro (2009: 7) beberapa masalaah yang sering menghambat seseorang ketika menulis anatara lain: sulit mendapat referensi, sulit mendapat tema, kesulitan menyusun kalimat baku.

Penelitian yang dilakukan di MAN 1 Surakarta ini berusaha mendeskripsikan kemampuan menulis hikayat Abu Nawas menggunakan media video sebagai perangsang mengembangkan kemampuan berbahasa siswa. Melalui penggunaan video diharapkan mampu mempengaruhi perkembangan bahasa siswa sehingga siswa dapat terampil dalam menulis, dan diharapkan siswa akan lebih mudah dalam mengatasi masalahmasalah yang sering ditemukan oleh seseorang ketika menulis. Untuk mengukur kemampuan menulis siswa, peneliti melakukan dengan cara mengevaluasi (memberikan penilaian) terhadap hasil pekerjaan siswa. Proses penilai merupakan proses yang memberikan maupun menentukan nilai kepada suatu objek berdasarkan kriteria tertentu (Sudjana, 2012:3). Kegiatan evaluasi sangat perlu dilakukan dengan tujuan untuk lebih baik kedepannya dalam membangun suatu hasil yang sudah dilaksanakan sebagai bahan motivasi selanjutnya. Kegiatan evaluasi sangat berguna bagi guru karena mellaui kegiatan tersebut, guru dapat menilai kualitas kemampuan peserta didik.

Penelitian yang serupa dengan penelitian ini pernah dilakukan oleh Rahayu, Maryatin, \& Retnowaty (2018). Pada penelitian yang dilakukan Rahayu, Maryatin, \& Retnowaty mendeskripsikan hasil kemampuan berbicara siswa kelas VIII. Hasil penelitian menyimpulkan bahwa hasil penilaian yang diperoleh oleh siswa kelas VIII di MTs Hidayatul Mustaqim dalam predikat baik. Hal ini dapat dilihat dalam skor akhir penilaian 
yaitu: 3 siswa atau sebesar 7.3\%, kategori baik sebanyak 20 siswa atau sebesar $48.78 \%$, kategori cukup baik sebanyak 12 siswa atau sebanyak $29.26 \%$, kategori kurang sebanyak 0 siswa atau $0 \%$. Persamaan penelitian ini dengan penelitian sebelumnya adalah sama-sama mendeskripsikan nilai akhir siswa. Perbedaan terletak pada objek penelitian yaitu teks tulis dan kemampuan berbicara siswa.

\section{Metode Penelitian}

Penelitian ini termasuk dalam penelitian deskriptif kaulitatif. Riyadi (2017) mengatakan bahwa secara umum penelitian kualitatif berupa analisis deskripsi kejadian, interaksi antarpartisipan, dan analisis dokumen. Dalam penelitian ini, peneliti mendeskripsikan hasil karya menulis siswa. Penelitian ini dilakukan pada tahun 2018 di MAN 1 Surakarta. Adapun kelas yang dijadikan sebagai subjek dalam penelitian ini yaitu kelas $\mathrm{X}$ IPA 1 yang memiliki jumlah 34 siswa. Teknik yang digunakan dalam pengumpulan data pada penelitian ini menggunakan teknik tes tertulis. Jenis tes tertulis yang diberikan kepada siswa yaitu teks hikayat. Siswa diminta untuk menceritakan kembali video hikayat Abu Nawas yang sudah disaksikan dalam bentuk cerita tulis. Berdasarkan instrumen tes yang diberikan, maka penilaian yang diberikan terdiri dari 4 komponen. Keempat komponen tersebut meliputi aspek tata bahasa, isi, gaya penceritaan, dan ejaan. Setiap komponen aspek memiliki skor 25 poin. Jika dalam keempat komponen aspek mendapat skor 25, maka jumlah skor akhir yang diperoleh adalah 100 poin. Adapun langkah analisis yaitu: mengoreksi hasil tulisan yang sudah dikumpulkan oleh siswa, memberi skor atau penilaian pada setiap karya siswa berdasarkan kriteria tersebut, selanjutnya peneliti mengolah nilai dengan menngunakan rumus.

$\mathrm{M}=\left(\sum \square \mathrm{F} \mathrm{X}\right) / \mathrm{N}$

Keterangan:

$\mathrm{M}=$ Rata-rata

$\mathrm{F}=$ Frekuensi

$\mathrm{X}=$ Nilai akhir

$\mathrm{N}=$ jumlah siswa

\section{Pembahasan}

Penilaian yang dilakukan pada karya siswa kelas X IPA 1 ini bertujuan untuk mendeskripsikan hasil kemampuan menyimak siswa. Penilaian ini bertumpu pada 4 komponen aspek. Hasil akhir penilaian dijadikan acuan dalam mengukur kemampuan siswa dalam keterampilan berbahasa dalam pembelajaran sekaligus untuk meningkatkan kualitas siswa. Penilaian dilakukan dengan rincian seperti pada tabel 1 Mudofir, dkk (2015).

\section{Aspek Tata Bahasa}

Tata bahasa mencangkup aturan-aturan yang berlaku dan harus digunakan oleh penulis. Tulisan dapat dikatakan bagus dan berkualitas apabila dalam penulisannya memperhatikan penggunaan tata bahasa yang sesuai dengan kaidah berbahasa Indonesia yang baik dan benar. Kesalahan dalam penerapan tata bahasa dapat mempengaruhi kualitas sebuah karangan. Aspek yang dinilai dari tata bahasa yaitu penggunaan PUEBI dan penggunaan kalimat efektif. penggunaan PUEBI dan keefektifan kalimat dalam sebuah karya tulis memang sangat diperlukan. Hal ini bertujuan agar tulisan yang dibuat dapat mudah dipahami. Penilai Penilaian hasil tulisan siswa dalam aspek tata bahasa dapat dikatakan baik. Hal ini dapat dilihat dari aspek tata bahasa, siswa yang mendapat nilai 5 ; 1 orang, siswa yang menilai $10 ; 2$ orang, siswa yang mendapat nilai 15 ; 22 orang dan siswa yang mendapat $25 ; 3$ orang. Akan tetapi masih terdapat beberapa contoh kalimat yang tidak sesuai dengan PUEBI maupun keefektifan kalimat dalam tulisan siswa. Berdasrkan hal tersebut maka rata-rata penilaian dalam karangan siswa adalah sebagai berikut.

$$
\begin{aligned}
\mathrm{M} & =\left(\sum \square \mathrm{F} \mathrm{X}\right) / \mathrm{N} \\
& =555 / 34 \\
& =16,32
\end{aligned}
$$

Berdasarkan penilaian diatas maka dampat disimpulkan bahwa rata-rata penilaian tulisan teks hikayat siswa dalam aspek penilaian tata bahasa adalah 16, 32 .

\section{Penilaian Aspek Isi}

Isi karangan merupakan intisari dari sebu-

Tabel 1.

Rentang Predikat Nilai

\begin{tabular}{|l|l|}
\hline Nilai & Keterangan \\
\hline$<60$ & Kurang \\
\hline $60-73$ & Cukup \\
\hline $74-87$ & Baik \\
\hline $88-100$ & Sangat baik \\
\hline
\end{tabular}


ah tulisan. Isi dalam sebuah karangan berisi informasi yang sudah didapatkan melalui kegiatan menyimak yang sudah dilakukan. Penilaian dalam aspek isi mencangkup isi cerita yang disampaikan. Penilaian isi lebih menekankan sampai sejauh mana siswa mampu memahami isi atau garis besar cerita dalam video, yang di ceritakan dalam tulisan. Hasil dari segi penilai isi menunjukkan bahwa seluruh siswa mampu memahami maksud cerita dalam video, hanya ketika mereka mengungkapkan dalam bentuk tulisan masih susah. Hal ini dilihat dari beberapa siswa dalam mengungkapkan cerita masih susah meskipun inti dari apa yang dituliskan mudah dipahami.

Hasil penilaian isi dalam karangan siswa diantaranya: siswa dengan nilai 5; 0 orang, siswa dengan nilai 10; 3 orang, siswa dengan nilai 15; 9 orang dan siswa dengan nilai 20; 9 orang, dan siswa dengan nilai $25 ; 13$ orang. Hasil dari jumlah tersebut dapat disimpulkan bahwa rata-rata penilaian tulisan teks hikayat siswa dalam aspek penilaian isi adalah 17, 42. Dilihat dari nilai yang diperoleh oleh siswa tersebut, membuktikan bahwa penggunaan isi dalam karangan siswa dalam teks hikayat dapat dikatakan baik. Melalui penilaian tersebut juga dapat disimpulkan bahwa keterampilan menyimak siswa juga bagus. Penghitungan hasill rata-rata penilaian penggungkapan isi cerita dapat dilihat sebagai berikut.

$$
\begin{aligned}
\mathrm{M} & =\left(\sum \square \mathrm{F} \mathrm{X}\right) / \mathrm{N} \\
& =592,5 / 34 \\
& =17,42 \mathrm{~s}
\end{aligned}
$$

\section{Gaya bahasa}

Gaya bahasa lebih mengarah kepada pilihan kata atau diksi yang digunakan dalam karangan siswa. Penggunaan gaya bahasa dalam suatu karangan sangat penting Karena melalui penggunaan gaya bahasa akan mempengaruhi kulitas karangan. Aspek yang dinilai dalam komponen ini meliputi bagimana gaya bahasa yang digunakan dari masing-masing siswa. Gaya bahasa ini memiliki hubungan dengan isi yang disampaikan oleh penulis. Dalam karangan ini, ditemukan beberapa penggunaan gaya bahsa yang berbagai macam. Hal ini menunjukkan bahwa siswa telah mampu mempermainkan penggunaan gaya bahasa. Hal ini dapat dilihat melalui skor yang mereka terima. Siswa yang mendapat skor $5 ; 0$ orang, siswa yang mendapat skor $10 ; 2$ orang, siswa yang mendapat skor $15 ; 11$ orang, siswa yang mendapat skor $20 ; 15$ orang, dan siswa yang mendapat skor 25; 6 orang. Hasill rata-rata penilaian penggunaan gaya bahasa dapat dilihat sebagai berikut.

$$
\begin{aligned}
\mathrm{M} & =\left(\sum \square \mathrm{F} \mathrm{X}\right) / \mathrm{N} \\
& =567 / 34 \\
& =16,67
\end{aligned}
$$

Berdasrkan penilaian diatas maka dampat disimpulkan bahwa rata-rata penilaian tulisan teks hikayat siswa dalam aspek penilaian gaya bahasa adalah 16, 67. Melalui hasil perhitungan tersebut dapat disimpulkan bahwa siswa sudah mampu dalam menggunakan gaya bahasa dalam karangan mereka. Hal tersebut terbukti bahwa dalam karangan siswa tersebut dapat dikatakan baik.

\section{Ejaan}

Penggunaan tanda baca atau ejaan dalam sebuah tulisan juga mendapat perhatian khusus. Penerapan ejaan dan tanda baca yang salah dapat mengakibatkan karangan menjadi tidak komunikatif sehingga akan sulit dalam memahami inti dari sebuah bacaan. Penilaian Ejaan memuat tanda baca yang digunakan oleh siswa dalam menulis teks hikayat Abu Nawas. Penggunaan ejaan dalam karangan menulis sangat perlu untuk diperhatikan karena penggunaan tanda baca turut mempengaruhi penyampaian kalimat dalam sebuah paragraf. dalam hasil karangan menulis siswa, dapat disimpulkan bahwa siswa kelas X IPA 1 telah mampu dalam penggunaan dan penerapan ejaan tanda baca. Rata-rata penggunaan tanda baca oleh siswa sudah dapat dikatakan sempurna hanya saja masih ditemukan beberapa kesalahan dari karangan siswa.

Hasil penilaian tanda baca dalam karangan siswa diantaranya: siswa dengan nilai $10 ; 2$ orang, siswa dengan nilai 15; 7 orang, siswa dengan nilai 20; 23 orang dan siswa dengan nilai 25 ; 2 orang. Dilihat dari nilai yang diperoleh oleh siswa tersebut, membuktikan bahwa penggunaan penggunaan tanda baca siswa dalam karangan teks hikayat dikatakan baik. Hal ini dapat dilihat melalui rata-rata penilaian penggunaan tanda baca sebagai berikut.

$$
\begin{aligned}
\mathrm{M} & =\left(\sum \square \mathrm{F} \mathrm{X}\right) / \mathrm{N} \\
& =559 / 34 \\
& =16,44
\end{aligned}
$$

Berdasarkan penilaian diatas maka dampat disimpulkan bahwa rata-rata penilaian tulisan teks hikayat siswa dalam aspek penilaian ejaan adalah 16, 44 .

\section{Perhitungan Nilai Rata-Rata}

Tes menulis karanagn merupakan salah satu tes yang bertujuan untuk melatih keterampilan berbahasa siswa. Melalui kegiatan menulis, siswa diharapkan juga dapat mengembangkan 
keterampilan berbicara, menyimak dan membaca. Kelebihan dari tes ini adalah simple dan mudah dilakukan oleh guru dan juga siswa. Namun kelemahannya adalah dalam memberikan penilaian kepada hasil karangan siswa tidaklah mudah. Hal ini disebabkan karena masing-masing siswa memiliki kemampuan dalam mengemukakan gagasan yang berbeda-beda. Sehingga dalam memberikan penilaian kepada hasil karanagn siswa, guru harus benar-benar konsentrasi tinggi. Berdasarkan pemerolehan nilai rata-rata yang sudah dijabarkan tersebut diatas, maka selanjutnya adalah perhitungan rata-rata nilai kemampuan menulis siswa dapat dilihat pada rumus di bawah ini.

$$
\begin{aligned}
\mathrm{M} & =\left(\sum \square \mathrm{F} \mathrm{X}\right) / \mathrm{N} \\
& =2640 / 34 \\
& =77,64
\end{aligned}
$$

Berdasarkan hasil evaluasi kemampuan menulis cerita hikayat, nilai keseluruhan yang diperoleh siswa berjumlah 2640. Jumlah hasil keseluruhan tersebut kemudian dibagi sesuai dengan jumlah siswa dan memperoleh hasil sebesar 77,64. Hasil penelitian menunjukkan bahwa terdapat 4 siswa yang belum tuntuas, 13 siswa menunjukkan hasil yang cukup, 17 menujukkan hasil yang baik.

\section{Kesimpulan}

Berdasarkan hasil uraian yang telah dikemukakan tersebut diatas dapat disimpulkan bahwa penggunaan media sangat berpengaruh dalam proses pembelajaran. Media hadir sebagai bentuk rangsangan kepada peserta didik agar pesan yang ingin disampaikan oleh pendidik dapat dipahami dengan mudah oleh peserta didik. Penggunaan media video sebagai bahan ajar dalam materi teks Hikayat di kelas X IPA 1 MAN 1 Surakarta sangat berpengaruh dalam kemampuan menulis siswa. Dengan adanya media video hikayat Abu Nawas sebagai media pembelajaran siswa, siswa lebih mudah dalam mengungkapkan gagasannya dalam bentuk tulisan. Hasil yang diperoleh dari penelitian ini menunjukkan bahwa tingkat kemampuan menulis siswa dalam keadaan baik. Hal ini dilihat dari hasil rata-rata penilaian akhir dari kegiatan menulis teks hikayat abu nawas yaitu 77,64. Hasil penelitian ini Selanjutnya dapat dijadikan acuan bagi guru bahasa Indonesia untuk terus dapat meningkatkan keterampilan berbahasa siswa hingga hasilnya dapat dikatakan sangat baik.

\section{Daftar Pustaka}

Chaer, A. (2013). Pembinaan Bahasa Indonesia. Jakarta: PT Rineka Cipta.
Jihad, A. (2013). Menjadi Guru Profesional: Strategi Meningkatkan Kualifikasi dan Kualitas Guru Di Era Global. Yogyakarta: Esensi.

Karim, M. (2015). Menyeldidik Sastra Melayu. Yogyakarta: Histokultura.

Kuncoro, M. (2009). Mahir Menulis: Kiat Jitu Menulisa Artikel, Opini, Kolom dan Resensi Buku. Jakarta: PT Gelora Aksara Pratama.

Kurniawan, H. (2015). Pembelajaran Kreatif Bahasa Indonesia (Kurikulum 2013). Jakarta: Prenadamedia Group.

Lestari, E., \& Wahyuni, O. (2016). Peningatan Keterampilan Menulis Paragraf Argumentasi Menggunakan Model Cooperative Think Pair Share Pada Siswa Kelas X C SMA Negeri 5 Singkawang. Jurnal Pendidikan Bahasa Dan Sastra Indonesia, 1(1), 17-22.

Mudofir, \& dkk. (2015). Buku Panduan Akademik 20152016. Surakarta: IAIN Press.

Rahayu, D., Maryatin, \& Retnowaty. (2018). Kemampuan Berbicara Siswa Mts Hidayatul Mustaqim Balikpapan Melalui Kegiatan Menjadi Pembawa Acara. BASA TAKA, 1(1), 22-29.

Riyadi, S. (2017). Metode Penelitian Kualitatif Kebahasaan. Surakarta: UNS press.

Rohmadi, M., Sugiri, E., \& Aninditya, S. N. (2014). Belajar Bahasa Indonesia: Upaya Terampil Berbicara dan Menulis Karya Ilmiah. Surakarta: cakrawala media.

Sari, R. (2007). Pembelajaran Bahasa Inggris Pendekatan Qur'ani. Malang: UIN-Malang Press.

Slamet. (2014). Pembelajaran Keterampilan Berbahasa Indonesia: Teori dan Aplikasi. Yogyakarta: Graha Ilmu.

Solihatin, E. (2013). Strategi Pembelajaran PPKN. Jakarta: PT Bumi Aksara.

Sudjana, N. (2012). Penilaian Hasil Proses Belajar Mengajar. Bandung: PT Remaja Rosdakarya.

Suyudi, Mardian, \& Wahyuni, O. (2016). Peningkatan Keterampilan Menulis Rangkuman Menggunakan Model Cooperative Integrated Reading And Composition Kelas VII B SMP Negeri 8 Singkawang Tahun Pelajaran 2015/2016. Jurnal Pendidikan Bahasa Dan Sastra Indonesia, 1(1), 6-11.

Tarigan, H. G. (2008). Berbicara Sebagai Keterampilan Berbahasa. Bandung: Percetakan Angkasa.

Tarigan, H. G. (2015). Pengajaran Pragmatik. Bandung: CV. Angkasa. 